\title{
ACCELERATION OF BONE FRACTURE HEALING THROUGH THE USE OF NATURAL BOVINE HYDROXYAPATITE IMPLANT ON BONE DEFECT ANIMAL MODEL
}

\author{
Junaidi Khotib ${ }^{1}$, Cantika SC Lasandara ${ }^{2}$, Samirah $^{1}$, Aniek S Budiatin ${ }^{1}$ \\ ${ }^{1}$ Department of Clinical Pharmacy, ${ }^{2}$ Postgraduate Student of Master of Pharmaceutical Science, Faculty of Pharmacy, \\ Universitas Airlangga, Surabaya, Indonesia
}

\section{ABSTRACT}

\begin{abstract}
Bone is an important organ for supports the body that stores reserve of calcium, phosphorus, and other minerals. In fracture conditions where bleeding, soft tissue edema, nerve damage, and blood vessels around the bone damage happen, they can cause the mobilization of these minerals in the surrounding tissue. One of the efforts made in the treatment of these fractures is reconnection, in which it works by filling of bone defect with a matrix and administration of anti-infection. Biomaterial filling in defective bone is thought to accelerate the healing process of bone fracture and prevent osteomyelitis. For this reason, this study evaluates the acceleration of bone fracture healing using natural hydroxyapatite (NHA) bone filler in rabbits with bone defect model. Fracture modeling was performed by surgical technique and drilling of bones with a $4.2 \mathrm{~mm}$ diameter to form a defect in the rabbit femur. Bone implant contained bovine hydroxyapatite-gelatin-glutaraldehyde (BHA implant) or bovine hydroxyapatite-gelatinglutaraldehyde-gentamicin (BHA-GEN implant) that was inserted in bone defects. 27 rabbits were divided into 3 groups: the control group who had bone defect, the bone defect group was given BHA implant and the bone defect group was given BHA-GEN implant. Observation of osteoclast, osteoblast, osteocyte, BALP level, and bone morphological integrity was carried out on the $14^{\text {th }}$, $28^{\text {th }}$, and $42^{\text {nd }}$ days after surgery. Histological observation of rabbit femur showed a significant difference on the number of osteoclast, osteoblast and osteocyte in all three groups. The BALP level also showed a significant difference in the group given the natural BHA bone implant compared to the control group on day $14(p=0.0361)$. Based on the result of the $X$-ray, there was also a better integration of rabbit femur bone in groups with the use of BHA or BHA-GEN bone implant. Thus, it can be concluded that the use of a natural BHA implant can accelerate the process of bone repair in the fracture of rabbit femur. In addition, BHA implants were compatible as a matrix for supporting the bone cell growth.
\end{abstract}

Keywords: Bone remodeling; fracture; natural bovine hydroxyapatite; bone alkaline phosphatase

ABSTRAK

Tulang merupakan organ penting penyangga tubuh yang menyimpan cadangan kalsium, fosfor dan mineral lainnya. Pada keadaan fraktur dimana terjadi perdarahan, edema jaringan lunak, kerusakan saraf dan kerusakan pembuluh darah di sekitar tulang dapat menyebabkan terjadinya mobilisasi mineral tersebut pada jaringan sekitarnya. Salah satu upaya yang dilakukan dalam penanganan patah tulang adalah penyambungan kembali, pengisian defek tulang dan pemberian anti infeksi. Pengisian biomaterial pada tulang yang defek diduga dapat mempercepat proses penyembuhan tulang yang patah dan mencegah terjadinya infeksi. Untuk itu pada penelitian ini dilakukan pengujian dengan menggunakan natural bone filler bovine hydroxyapatite (NHA) dalam penanganan defek tulang pada hewan coba kelinci. Pembuatan model fraktur dilakukan dengan teknik pembedahan dan pengeboran tulang dengan mata bor $4.2 \mathrm{~mm}$ sehingga terbentuk defek (lubang) pada tulang femur kelinci. Implan tulang yang mengandung bovine hydroxyapatite (implan BHA) atau bovine hydroxyapatite dengan antibiotika gentamisin (implan BHA-GEN) disisipkan pada defek tulang yang telah dibuat. 27 ekor kelinci dibagi dalam 3 kelompok yaitu kelompok kontrol yang mengalami defek tulang, kelompok defek tulang dengan pemberian BHA dan kelompok defek tulang dengan pemberian BHA-GEN. Pengamatan osteoklas, osteoblas, osteosit, kadar BALP dan keutuhan morfologi tulang dilakukan pada hari ke 14, 28 dan 42 setelah operasi. Pengamatan histologi pada tulang femur kelinci menunjukkan adanya perbedaan signifikan jumlah osteoklas, osteoblas dan osteosit pada ketiga kelompok. Kadar BALP juga menunjukkan perbedaan bermakna kelompok yang diberikan implan BHA atau BHA-GEN dibanding kelompok yang tidak diberikan implan tulang pada hari ke-14 $(p=0,0361)$. Berdasarkan hasil X-Ray juga terjadi penyatuan yang lebih baik tulang femur kelinci pada kelompok dengan penggunaan implan tulang. Dengan demikian dapat disimpulkan bahwa penggunaan natural implan BHA dapat mempercepat proses perbaikan tulang pada femur kelinci yang mengalami fraktur dan BHA mempunyai compatibilitas yang baik sebagai matriks pendukung pertumbuhan sel tulang.

Kata kunci: Bone remodeling; fracture; natural bovine hydroxyapatite; bone alkaline phosphatase

Correspondence: Junaidi Khotib, Department of Clinical Pharmacy, Faculty of Pharmacy, Universitas Airlangga, Surabaya, Indonesia. E-mail: junaidi-k@ff.unair.ac.id

pISSN:2355-8393 • eISSN: 2599-056x • doi: http://dx.doi.org/10.20473/fmi.v55i3.15495

- Fol Med Indones. 2019;55:176-187 • Received 10 May 2019 • Accepted 24 Aug 2019

- Open access under CC-BY-NC-SA license • Available at https://e-journal.unair.ac.id/FMI/ 


\section{INTRODUCTION}

Bone is one of the most important parts of the human body cantilever, serves as a support for muscle, protects vital organs such as the brain and thoracic cavity, and is where bone marrow forms blood cells. Bone is also a storage place for calcium, phosphorus, and other ions that can be released or stored to maintain a constant level of these ions in body fluid (Seibel 2000, Pagani 2005). Fracture is a condition of bone continuity that results from direct or indirect injury. In a fracture, the surrounding tissue will also be affected where soft tissue edema will occur, bleeding, nerve damage, and blood vessels around the bone damage (Brunner 1997, Einhorn 2010).

In Indonesia, the number of fracture event is quite high. Based on the data from the Ministry of Health of the Republic of Indonesia, eight million people experience fracture events with different types and causes. From the Ministry of Health's survey report, it is found that $25 \%$ of patients with fractures have died, $45 \%$ have physical disabilities, $15 \%$ have lost some bones and suffered injuries, and $10 \%$ have recovered well. One effort that has been developed to reduce the occurrence of bone defect and overcome the problem of bone gap is the use of bone graft. Bone graft is a surgical procedure that places new bone or substitute material (composite matrix) into the space around a fracture or where it has a gap (defect) (Helmi 2014). In the use of bone graft, it will stimulate the process of osteogenesis through osteoblast activation in the area around the defect. In addition to osteoconductive, there is an osteoinductive process, which is related to the formation of new bone through the stimulation of osteoprogenitor cell that comes from the defect to differentiate into osteoblast and form new bone (Ferdiansyah et al 2010).

Metabolically active bone undergoes continuous remodeling through two processes, namely the formation and resorption of bone. These processes depend on the activity of osteoclast, osteoblast, and osteocyte. These active and dynamic processes depend on the balance between the process of bone resorption by osteoclast and bone deposition by osteoblast. These two functions must be balanced both quantitatively and functionally (Chen et al 2012, Sihombing et al 2012).

Implant inserted in bone defect can also contain an antibiotic that works locally to prevent infection. The release of antibiotic is done with a modified release design so that it can cover during the bone healing process. One way to do this is to add a composite with cross-link agent (crosslinking material). Some chemicals that can be used as cross-link ingredients are proteins, including glutaraldehyde, formaldehyde, polyepoxy, acylazide, carbodimiides, and hexamethylene diisocyanate (Marsell et al 2011, Budiatin et al 2013, Schlickewei et al 2013). Preliminary research shows that the cross-link ingredients such as glutaraldehyde (GA) has advantages such as being soluble in water, requiring low concentrations, forming covalent bonds, and having low boiling point $\left(40^{\circ} \mathrm{C}\right)$. The residue can be removed by washing or heating while drying the granule for 24 hours at $40^{\circ} \mathrm{C}$, and accelerating calcification in tissue defect (Budiatin et al 2014). Gentamicin is a bactericidal choice of antibiotic used as prophylaxis and the next stage of therapy. Gentamicin is released by diffusion from the matrix and penetrated into the bone (Budiatin et al 2013).

Fracture treatment requires a long time and the concentration of released antibiotic must be greater than the minimum inhibitory concentration (MIC) so that it can eradicate the bacteria that enter the bone during surgery. A matrix is needed as a carrier that is able to control the release of antibiotic that enters the local blood circulation to the site of infection at the remodeling stage. If infection can be avoided then the remodeling process runs quickly (Askarzadeh et al 2005, Azami et al 2012, Budiatin et al 2013).

Hydroxyapatite (HA) is the main inorganic component of bone, used in a variety of bone filling and replacement application because it has good biocompatible, biointegrating, and osteoconductive property (Capra et al 2011, Cattalini et al 2012, Chang et al 2015). However, HA has a disadvantage, in addition to its high price, HA as a synthetic material can also cause residual base ingredient to form hydroxyapatite. To overcome these weaknesses, natural hydroxyapatite which is an inorganic component of cow bone can be used as an alternative composite component which has several advantages including being more porous and having the ability to adsorb antibiotics as active ingredients such as antibiotics, hormones, or growth factors (Budiatin et al 2014). In addition, the natural composition of hydroxyapatite (NHA) derived from bovine bone consists of $93 \%$ of hydroxyapatite $\left(\mathrm{Ca}_{10}\left(\mathrm{PO}_{4}\right)_{6}(\mathrm{OH})_{2}\right)$ and $7 \%$ of $\beta$-tricalcium phosphate $\left(\mathrm{Ca}_{3}\left(\mathrm{PO}_{4}\right)_{2}, \mathrm{~B}-\mathrm{TCP}\right)$ and has properties similar to human bone minerals. NHA is also thought to have excellent biocompatibility, high bioactivity potential in bone tissue reconstruction, low biodegradation, and osteoconductive property (Kusrini et al 2012; Chang et al 2015). The biocompatible nature and great porosity of NHA cause it becomes insoluble and unabsorbed so that it is ideal to act as a substitution material in the formation of new bone (Cottrell et al 2010, Budiatin et al 2014). 
Gelatin is a protein produced from the collagen fiber of connective tissue, skin, bone, and cartilage hydrolyzed by acidic or basic process (Budiatin et al 2013). Gelatin is also produced by osteoblast to form osteoid (soft callus). By using the NHA matrix, it will be able to bind the active ingredients more strongly, besides that it is also biodegradable, biocompatible, bioresorptable, nontoxic, and can be united with the surrounding bone (Budiatin et al 2013; Budiatin et al 2014, Chao et al 2015). Gelatin as the main component in soft callus creation will quickly form a trabeculae that connects the two sides of the defect, so the bones are interconnected. BHA implant absorbs body fluid, expand, and form canals or occur vascularization, making it easier for cells to penetrate. BHA implant can function as an implant to proliferate and differentiate cell into osteocyte (hard callus) that closes the defect (Budiatin et al 2014). Bone growth begins with the formation of osteoid by osteoblast of which $90 \%$ of the main constituent is type 1 collagen which is the result of gelatin degradation in the implant. Degradation results from BHA implant that supports the process of bone remodeling by forming osteocytes. This phenomenon is a good process for accelerating the closure of bone defect (Raggatt \& Partridge 2010, Ramirez-Fernandez et al 2011). Bone growth can be evaluated semiquantitatively from the result of X-ray observation using Lane \& Sandhu scoring (Budiatin et al 2014).

Bone alkaline phosphatase (BALP) enzyme is a metalloenzyme that is produced when osteoblast cell is working (Ellis \& Kathleen 2007, Greenblatt et al 2017). BALP prepares an alkaline atmosphere in the formed osteoid tissue so that calcium can be easily deposited in the tissue. In addition, this enzyme causes an increase in phosphate concentration so that calcium-phosphate bonds are formed in the form of HA. Thus, BALP can be used as an initial marker of osteoblast differentiation and increase when progressive differentiation of osteoblast occurs (Boanini et al 2008, Goes et al 2012).

\section{MATERIALS AND METHODS}

This was an experimental study with post-test only control group design by using rabbits as the experimental animals with a fracture model on the femur. A total of 27 strained New Zealand rabbits aged between 4-8 months in health and no visible disruption in the rabbit femur were randomly divided into three groups namely the control group, the BHA implant group, and the BHA-GEN implant group. The rabbits were treated in a cage with a room temperature of $25 \pm$ $1^{\circ} \mathrm{C}$ with 12 hours of dark lighting and 12 hours of light in the Animal Laboratory, Faculty of Pharmacy, Universitas Airlangga, Surabaya. Food and water were maintained in sufficient quantities during the study. Before being treated, the rabbits were adapted to the environment for 2 weeks. Peripheral blood samples were taken through the ear vein for BALP base line examination before surgery and implantation. All maintenances and actions on experimental animals had received approval from the animal ethics committee of the Faculty of Veterinary, Universitas Airlangga, Surabaya.

Research materials used in this study were BHA and BHA-GEN implants, sterile purified water, $\mathrm{NaCl} 0.9 \%$ (pharmaceutical grade), ELISA Kit Catalog No. CSB-E 12088f, xylazine (pharmaceutical grade), gentamicin (pharmaceutical grade), ampicillin (pharmaceutical grade), ketamine (pharmaceutical grade), betadine, savlon, alcohol $70 \%$ (pharmaceutical grade). Whereas, the tools were Syringe injection $1 \mathrm{cc}$, bistoury surgical knife no. 15, bone drill, silk suture no 3.0, circle needles/surgical needles, light microscope, X-ray, and ELISA reader.

Natural bovine hydroxyapatite (NHA) (8 g) was added $20 \%$ gelatin $(5 \mathrm{ml})$ and/or $10 \%$ gentamicin and stirred until homogeneous to form a mass that could be made into granules. The granules were dried and then soaked in $2 \mathrm{ml}$ of $5 \%$ glutaraldehyde (GA) solution in saline phosphate buffer (SPB) to $100.0 \mathrm{ml}$. The granules were washed to GA free with distilled water and dried at $40^{\circ} \mathrm{C}$ for 24 hours, then weighed $100.0 \mathrm{mg}$ and compressed in a $4 \mathrm{~mm}$ diameter mold with a pressure of 0.5 tons (Budiatin et al 2014). Bone sample was immersed and fixed in $10 \%$ formalin for 3 days at room temperature. Furthermore, the decalcification process by immersion in ethylene diamine tetra acetic acid (EDTA) $10 \%$ was done at $\mathrm{pH} 7.4$ for 30 days at room temperature. $10 \%$ EDTA solution was replaced every 3 days.

The femur was irradiated with X-ray on days 14, 28 and 42 to determine the gap development (defect) of bone and integrity after implantation. After BHA and BHAGEN implants were irradiated for 14, 28 and 42 days, blood sample was taken through the rabbit ear vein. The serum was separated and used in the determination of BALP by the Elisa method. 100 microliter of serum was entered into the well and incubated at $370 \mathrm{C}$ in standard fluid for 2 hours. The filtrate was removed then added with 100 microliter of biotin antibody solution and incubated for 1 hour. The filtrate was removed and washed with washing buffer liquid for 3 times (5). Next, 100 microliters of horse radish peroxidase (HRP)-avidin conjugated solution were added and incubated for 1 hour at the temperature of $370 \mathrm{C}$. The filtrate was removed and washed with washing buffer for 3 times and added 90 microliters of tetra methyl blue (TMB) 
substrate liquid and incubated for 30 minutes in a dark room with the temperature of $370 \mathrm{C}$. The reaction was ended with the addition of a 50 microliter of stop solution liquid then read with a microplate reader at the wavelength of $450 \mathrm{~nm}$.

Histopathological approach with hematoxylin eosin (HE) staining was used for the examination of osteocyte, osteoblast, and osteoclast (Fischer et al 2008). Tissue pieces were stained with Hematoxylin Mayer's solution for 3 minutes. The slide was soaked in water for 5 minutes. Subsequently, it was dipped in alcohol 8-12 times and washed with running water for several minutes. Performing counterstaining in eosin working solution for 15 seconds to 2 minutes depending on the desired color level. It was later hydrated in serial alcohol concentrations with gradations increasing from $70 \%$ to $100 \%$, each for 2 minutes. The slide was cleared with xylene for $3 \times 15$ minutes. The calculation of the number of osteoblast, osteoclast, and osteocyte was using a digital 400 times magnification microscope as many as 10 fields.

The research data obtained were tested for normality using the Kolmogorov-Smirnov test followed by the Lavene test for equality of variances. Data analysis was performed with Anova test to compare between groups and continued with post-Hoc Turkey's HSD.

\section{RESULTS}

\section{Development of bone fracture animal model}

The study was conducted using 27 New Zealand rabbits aged 3-4 months old with the weight of $2.3 \mathrm{~kg}-2.5 \mathrm{~kg}$. The adaptation of the rabbits was carried out for 2 weeks and given standard feed and water in the amount of ad libitum. Rabbits were divided into 3 groups: fracture group (control) with 9 rabbits, fracture group that was given BHA (bovine hydroxyapatite-gelatinglutaraldehyde) implant with 9 rabbits, and fracture group that was given BHA-GEN implant (bovine hydroxyapatite-gelatin-glutaraldehyde-gentamicin) with 9 rabbits. Rabbits were anesthetized with xylazine 2 $\mathrm{mg} / \mathrm{kg}$ of body weight and ketamine $20 \mathrm{mg} / \mathrm{kg}$ of body weight. The furs of the rabbits were shaved and given povidone iodine antiseptic. Furthermore, the rabbit femur bone was incised and drilled. The bone fracture model was made by drilling until a $4.2 \mathrm{~mm}$ of bone defect occurred in the rabbit femur. Infection was prevented by intra-muscular ampicillin $25 \mathrm{mg} / \mathrm{kg}$ of body weight. Placebo or BHA implant or BHA-GEN implant (as in Fig 1) was mounted on the hole. The wound was cleaned with a cotton swab soaked in $\mathrm{NaCl}$ solution and sewn again. Furthermore, wound care was done every day. Observation of bone repair was monitored on days 14,28 , and 42 . The termination was carried out on day 42, rabbit femur was taken, and some biomarker parameters were set as markers of bone remodeling acceleration.

\section{The morphological observation of rabbit distal femur}

To determine the growth of rabbit bone morphology after implant placement in the fracture condition, rabbit surgery was performed from each control treatment group, BHA implant group, and BHA-GEN implant group. The bone was taken then histochemical prepared with HE staining, then the cell in the bone fragment was observed in 10 visual field with a light microscope at 100x magnification. Using $\mathrm{HE}$ staining, the control bone preparation for 42 days showed that the defect had formed a compact bone structure. Osteocytes had spread evenly in the lament that surrounded the heavers' duct (as in Figure 2). The new bone structure that was formed was thought to have density and structure that resembled the surrounding bone. Bone preparations from the BHA or BHA-GEN implant group for 14 to 42 postoperatively showed connective tissue that was still enveloping implant such as capsule, the connective tissue still did not appear to proliferate into the implant. The implant also looked intact. Figures 3 and 4 showed the change of new bone growth that was seen only in the edge of bone defect bordering the connective tissue that surrounded the BHA and BHA-GEN implants. This new bone tissue that growed up did not enter the implant. As a result there was no direct bond between the implant and bone tissue. There was a clear line between new bone tissue, connective tissue, and implant. The new bone tissue formed was still visible as woven bone formed in the early months of the bone healing process (bony callus). Woven bone could be seen from the form of its collagen fibers that were arranged randomly, as well as irregular vascular cavity shapes (Kalfas 2001, Einhorn 2010). The stage of bone growth was evaluated through the number of osteoclast, osteoblast, and osteocyte bone cells on days 14, 28, and 42 using a light microscope. The difference in growth visually could be seen in Figs. 2-4 and Table 1.

\section{Radiological examination from the development of bone defect healing}

The result of radiological observations with X-ray device could reveal the development of bone healing around the BHA and BHA-GEN implants starting on days 14, 28, and 42 as shown in Figures 5, 6, and 7. Treating without implantation and installation of a BHA or BHA-GEN implant showed the size of the defect was getting smaller through X-ray imaging result from days 14,28 , to 42 . 

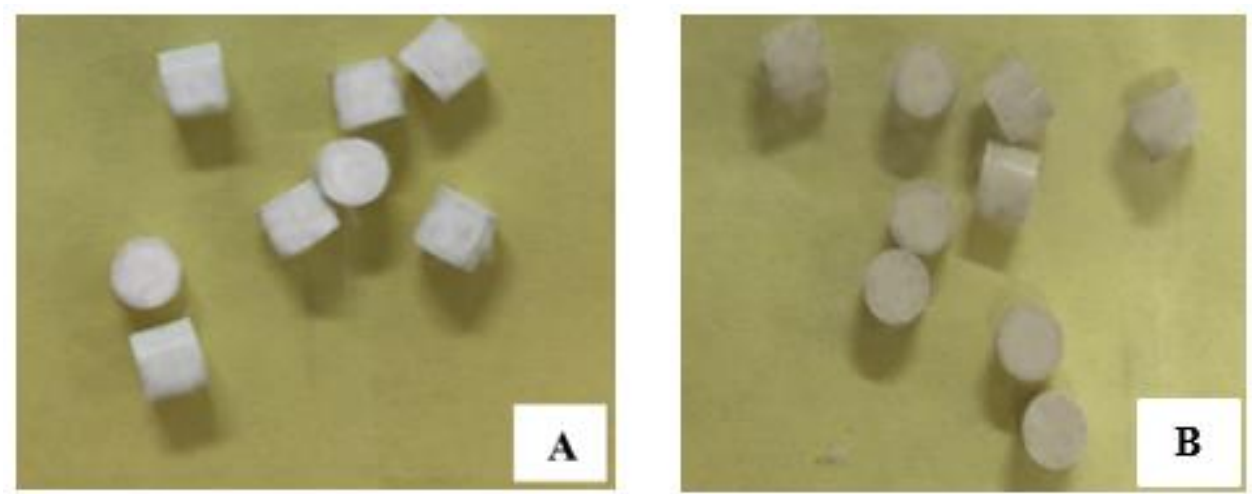

Fig. 1. Bovine hydroxyapatite-gelatin-glutaraldehyde/BHA (A) and bovine hydroxyapatite-gelatin-glutaraldehydegentamicin/BHA-GEN (B) implants with a diameter of $4.0 \mathrm{~mm}$ that were used as bone fillers in this study.

Table 1. The number of osteoclasts, osteoblasts, and osteocytes in the defective bone (fracture model) on days 14,28 and 42 after induction of bone defect and implant placement

\begin{tabular}{cccc}
\hline \multirow{2}{*}{ Group } & \multicolumn{3}{c}{ Average cell count $(\mathrm{X} \pm \mathrm{SD})$} \\
\cline { 2 - 4 } & Osteoclasts & Osteoblast & Osteocytes \\
\hline Control 14 & $0.66 \pm 0.57$ & $102.00 \pm 22.27$ & $185.00 \pm 80.55$ \\
Control 28 & $1.33 \pm 0.57$ & $112.33 \pm 10.96$ & $215.33 \pm 95.65$ \\
Control 42 & $2.50 \pm 0.70$ & $188.00 \pm 91.92$ & $131.50 \pm 47,37$ \\
BHA 14 & $2.66 \pm 1.54$ & $202.33 \pm 27.42$ & $191.66 \pm 44.11$ \\
BHA 28 & $2.66 \pm 0.57$ & $264.60 \pm 20.50$ & $299.00 \pm 40.13$ \\
BHA 42 & $3.00 \pm 0.70$ & $241.50 \pm 42.42$ & $241.00 \pm 14.14$ \\
BHA-GEN 14 & $3.33 \pm 1.52$ & $274.33 \pm 39.52$ & $277.60 \pm 23.77$ \\
BHA-GEN 28 & $3.50 \pm 0.70$ & $210.50 \pm 12.37$ & $204.50 \pm 37.46$ \\
BHA-GEN 42 & $3.00 \pm 1.73$ & $295.00 \pm 22.11$ & $308.50 \pm 36.50$ \\
\hline
\end{tabular}

\section{The result of BALP level analysis}

Bone alkaline phosphatase in the mineralization process served to prepare the alkaline atmosphere in the osteoid tissue that was formed so that calcium could be easily deposited in the tissue. In addition, this enzyme caused an increase in phosphate concentration so that calciumphosphate bonds were formed in the form of hydroxyapatite. Measurement of mineralization level was proportional to the level of BALP. On the 14th day, there was a significant difference in the level of BALP between the BHA and BHA-GEN treatments using Turkey's multiple comparison test (as in Table 2). BALP biomarker found in bone showed early differentiation of osteoblast from mesenchymal cell and played an important role in osteoid formation and mineralization by means of degradation from inhibitor mineralization. Alkaline phosphatase degraded matrix that was rich of proteoglycan and hydrolyzed high ester energy to provide phosphate ion resulting in the deposition of minerals with calcium in a collagen-rich matrix network. Determination of calcium and phosphate minerals with ALP could cause bone formation so that when bone formation could be improved, then the fracture healing could also be faster.

\section{DISCUSSION}

This research was conducted to examine the process of accelerating bone remodeling in the condition of a fracture or defect using the NHA composite biomaterial implantation in the form of BHA and BHA-GEN implants. NHA biomaterial composition obtained from bovine bone has similarity with bone composition in humans. BHA and BHA-GEN implants are thought to accelerate bone growth acceleration. This is because some components such as HA and gelatin can stimulate the activity of osteoblast to form osteoid where this process will accelerate the reaction of hard callus bone formation (osteocyte). For this reason, the development of fracture model in the femur illustrates a state of continuity of bone continuity so that it is very appropriate for the use of implant in an effort to connect broken bones. Making a fracture model is done by drilling a bone method with a $4.2 \mathrm{~mm}$ drill bit to form a 
defect (hole). Thus, the implantation of BHA and BHAGEN with a diameter of $4.0 \mathrm{~mm}$ in rabbit femur can be done well. The process of healing fracture and repairing bone tissue involves an initial anabolic phase characterized by an increase in tissue volume associated with de novo recruitment and differentiation of stem cell that form bone and Callus cartilage tissue blood vessel around the fracture area. This process will occur from the periphery to the center of the fracture to the end of the cartilage network (Einhorn 2010, Einhorn \& Gesternfeld 2015, Hikmawati et al 2019).

The use of autograph, for bone defects is very limited due to donor limitation, causing pain and damage to the part taken. Defect causes damage to blood vessel, connective tissue, and surrounding muscle tissue which will affect the duration of healing of the defect. Given this limitation, it is necessary to have suitable biomaterials as bone replacements or implants (Schlickewei et al 2015, Ning et al 2017). Bone is externally covered by a tissue called the periosteum. Periosteum contains blood vessel, thick layer of collagen fiber that is arranged in a dense irregularity, and cell that is able to differentiate into osteoblast (osteogenic cell). All parts of the bone are covered by the periosteum, except those which are articulated with other bones. Bone has an internal space in the middle of the marrow cavity, in which there is stem cell from blood cell. The marrow cavity is coated by a layer of thin vascularized connective tissue called the endosteum. Endosteum also has osteogenic cell as does the periosteum (Kalfas 2001, Kim et al 2004, Maulida et al 2015).

Bone is composed of three main cell types, namely osteoblast, osteocyte, and osteoclast. Osteoblast is a cell that plays a role in the activity of bone organic component synthesis, which is referred to as prebone or osteoid. Osteoblast is located in a line along the surface of bone tissue. When active, osteoblast tends to be cube shaped and basophilic in nature. Meanwhile, when less active, the shape will become more flat and less basophilic. HE staining is often used and able to daub the nucleus and cytoplasm, HE staining uses 2 kinds of staining agents namely hematoxylin which functions to daub the cell nucleus and gives a blue color and eosin which is used to daub the cytoplasm of cells (Fischer et al 2008). Histological testing of rabbit femur bone from each control treatment group, the BHA implant group, and the BHA-GEN implant group is to determine the bone growth process that occurred after the fracture. The method used in this examination is a quantitative method, which is determined by adding all the target cells found in 10 (ten) different visual fields with a magnification of 100 times.
In the process of bone fracture healing, it appears that the control group without implant provides a slow response in the activation of debris removal cell. In the next phase, osteoblast cell activation occurs to begin the process of bone formation. At the macroscopic observation, the bone defect has been covered by a mass of tissue. This result is clarified by macroscopic examination. On the 14th day through the 42nd days postoperatively, the mass of the tissue is bone growth. At some locations, the trabecular bone grows near the edge of the bone near the periosteum showing osteoblastic activity. Most of the bones have formed compact structure (Fig. 2).

Based on microscopic observations (3-4), the bone filled with decalcified BHA implant on the 14th day until the 42nd day postoperatively has shown a proliferation of connective tissue into the implant. These results indicate that BHA is type 1 collagen, visible implant response that has formed trabeculae/bone sponge perfectly on day 42, has osteoconductive property. According to Kalfas (2001), osteoconductive is the physical nature of graft in carrying out functions as an implant to support bone healing. Biomaterial that has osteoconductive property allows for the growth of osteogenic precursor cells into graft space.

The growth of osteoblast into osteocyte in the bone indicates the degradation and tissue resorption of BHAGEN implant. The implant which expands to become porous will facilitate the cells around it to proliferate and penetrate, and differentiate within it. Osteoblast produces alkali phosphatase which functions to deposit calcium and phosphate into osteoid, osteoid will quickly form between BHA-GEN implant, because BHA implant component consists of calcium and phosphate. The bone marrow space contains many blood vessels and fat cells (Fig. 5), this shows the bone marrow is in a normal state. The implant is seen attached to the bone attached by connective tissue. In the BHA-GEN implant area with bone there is no inflammatory reaction because there is no inflammatory cell found in the area.

On microscopic examination between the control group and the BHA intake group or the BHA-GEN implant on the $14^{\text {th }}$ day to the $42^{\text {nd }}$ day postoperatively is analyzed using Two way ANOVA statistical analysis, showing a significant difference between the control group, the BHA, and BHA-GEN osteoblast $(\mathrm{p}<0.0074)$ and osteoclast ( $p<0.0008$ ) on the 14 th day through the 42 nd day, while in the osteocyte of the control group, BHA, and BHA- GEN there is no difference. In Table 1, the increased number of osteocyte shows the difference between days 14 and 42. On the other hand, osteoclast and osteoblast tend to increase in control, BHA, and BHA-GEN on the 14 th day to the 42 nd day. This shows 
that the earliest occurrence of osteoclast activity is to degrade the inorganic component of the bone matrix, namely the alkaline salt of bone mineral HA. In BHAGEN implantation, osteoblast also increases from the 14th day through the 42nd day, where the function of osteoblast synthesizes bone matrix protein and helps the calcification process.

The result of radiological observation with X-ray equipment on bone from the 14th day to the 42nd day is able to show the development of bone growth. The radiology of positive control bone taken on the 14th day to the 42nd day postoperatively from the lateromedially direction shows the existence of a round shape on the defect in the bone, showing a zone radiolucent round shape which indicates damage to the bone due to drilling that is left without being given bone implant (Fig. 5). Damage in the physical structure of the bone which means the loss of calcium in that part will cause a decrease in bone opacity. Margin of bone damage is very clear.On (Figs. 6 and 7) BHA implantation taken on the 14th day to the 42nd day postoperatively with LM view. On day 14, the implant form still looks intact white. Normally, the change in implant margination indicates a reaction between the implant and surrounding bone tissue, while the appearance of the radiolucent zone around the implant accompanied by a decrease in implant opacity indicates to see implant absorption on days 28 and 42 indicates the state of the defect has begun to close with soft callus, bone defect filled with BG implants undergoes regeneration or closure quickly, seen from the soft callus formation so the bones quickly reconnect. Askarzadeh et al. (2005) state that change in the shape of the implant (becoming smaller and blurred) and increasing degree of blurring until implantation are probably lost related to bone growth and osteoblastic activity. A change that occurs in bone radiograph with BHA implant is not accompanied by a decrease in opacity and change in the shape of the implant, so this change cannot be a strong indicator to show the absorption of the implant.

This is confirmed by the change that occurs in the radiographic image of BHA-GEN bone with $\mathrm{LM}$ view. The BHA-GEN implant seen on day 14 is also still in the form of a whole white sphere. A fairly good development is seen in the radiographic picture of BHA- GEN on day 28 (Fig. 7). Radiolucent strings are seen also on implant but still very fine. The change that occurs indicates the ongoing process of degradation and absorption of BHA-GEN implant and osteogenesis to form new bone tissue.
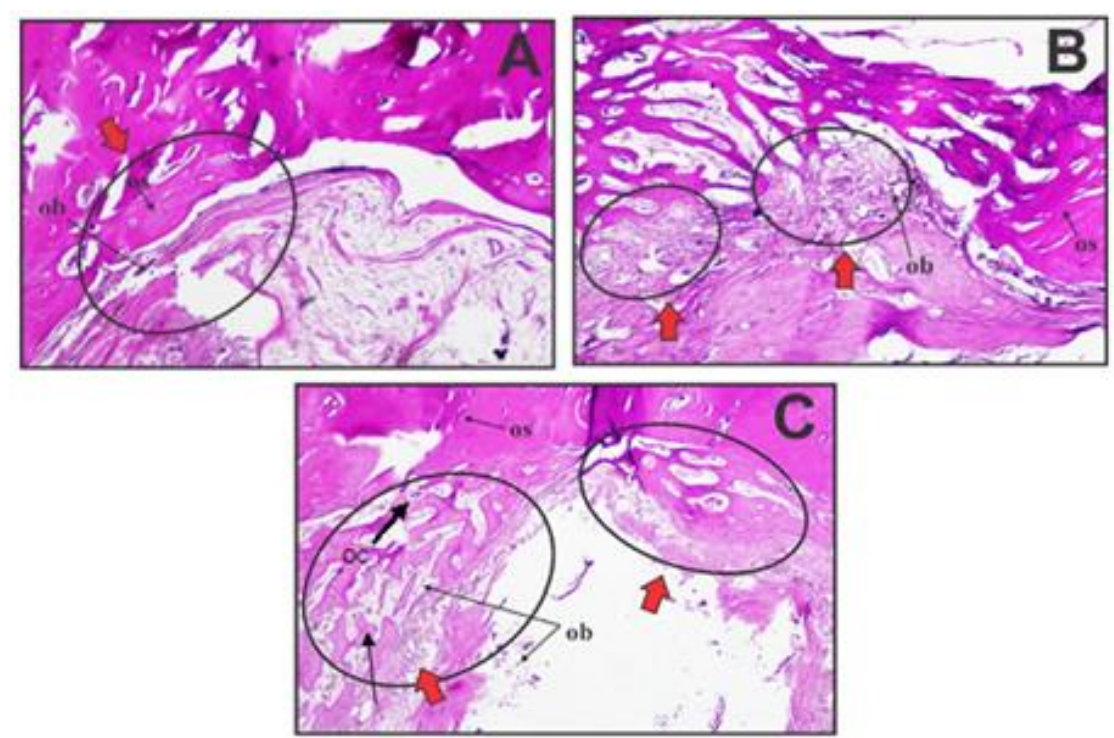

Description:

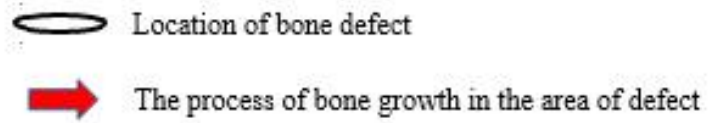

Fig. 2. Transversal section of the distal femur of the control group for 14 (A), 28 (B) and 42 (C) days after surgery. The pictures showed a new bone structure formed in the edge of the bone defect area that was defined above ob $=$ osteoblast, oc $=$ osteoclast, os $=$ osteocyte. The staining was using $\mathrm{HE}$ and the observation was using 100x magnification. 

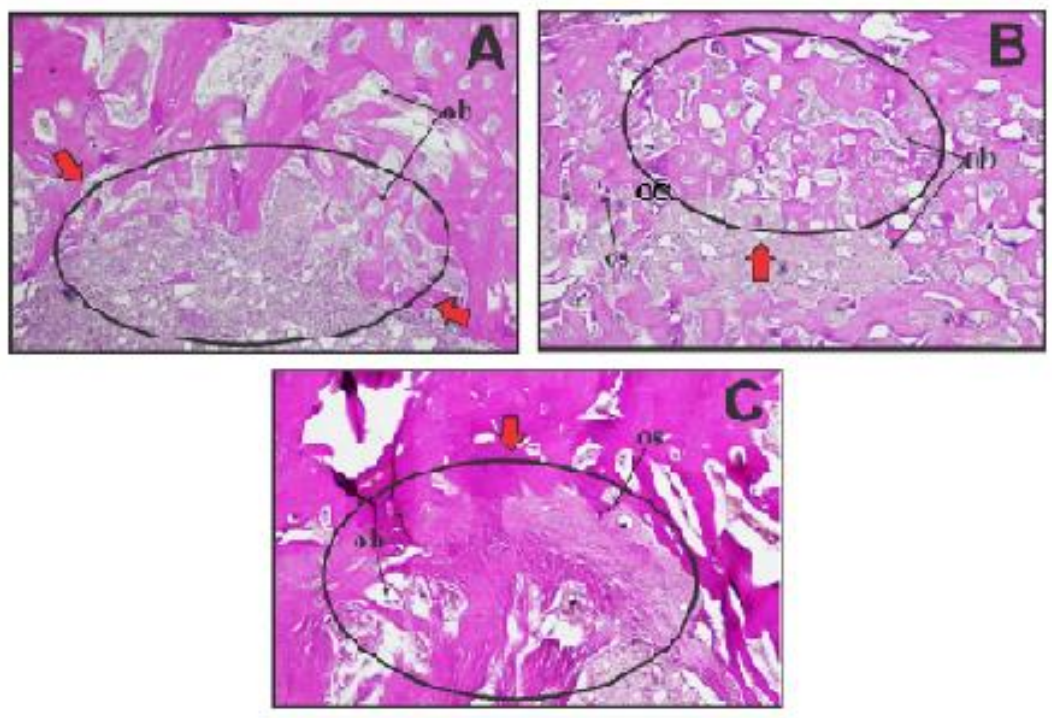

\section{Description: $\longrightarrow$ Location of bone defect \\ The process of bone growth in the area of bone defects}

Figure 3. Transversal section of the distal femur of rabbits given BHA implant on bone defect for 14 (A), 28 (B) and 42 (C) days after surgery. The pictures showed the new bone structure that formed in the edge of bone defect consisting of $\mathrm{ob}=$ osteoblast, $\mathrm{oc}=$ osteoclast, os $=$ osteocyte. The staining was using $\mathrm{HE}$ and the observation was using 100x magnification.

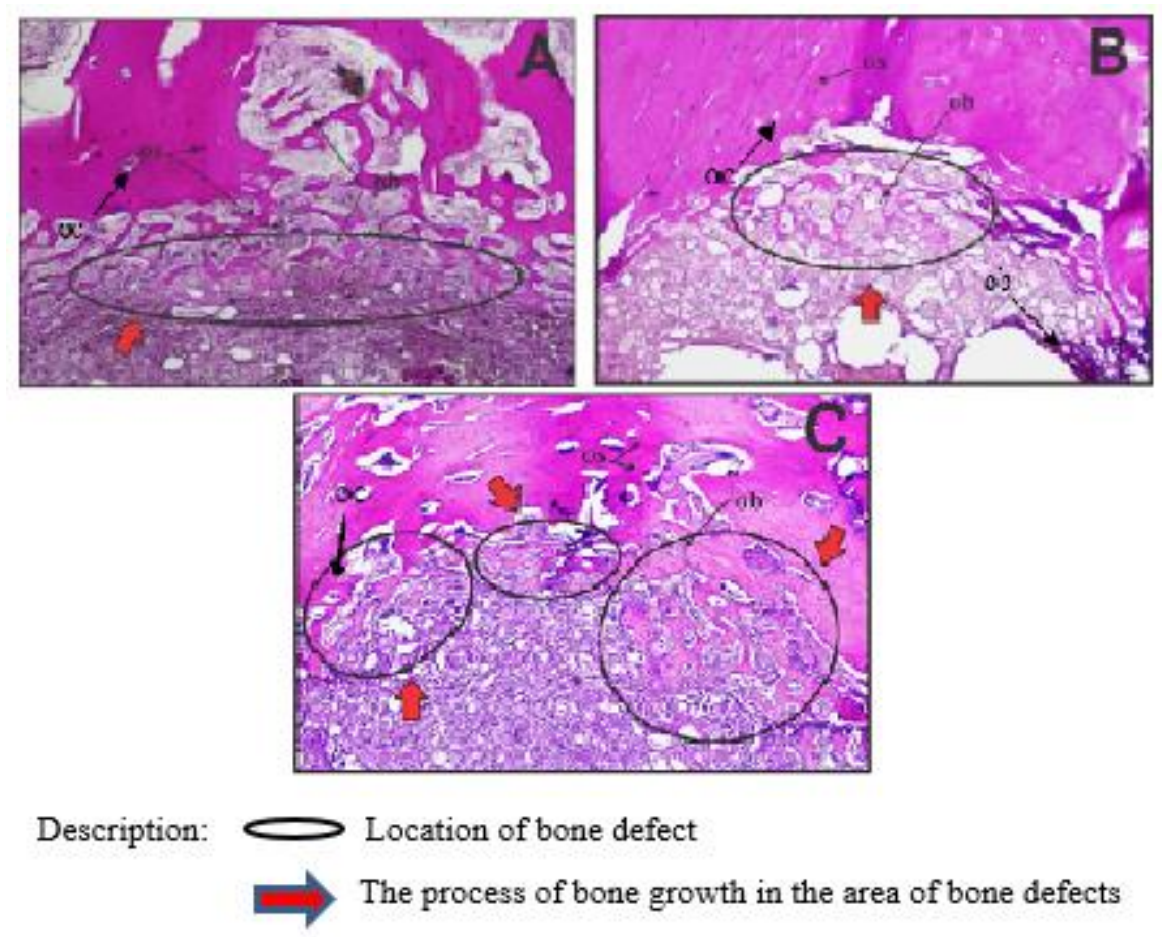

Fig. 4. Transversal section of the distal femur of rabbits given BHA-GEN implant on bone defect for 14 (A), 28 (B) and 42 (C) days after surgery. The pictures showed the new bone structure that was formed in the edge of bone defect that consisting of $\mathrm{ob}=$ osteoblast, $\mathrm{oc}=$ osteoclast, os $=$ osteocyte. The staining was using HE and the observation was using 100x magnification. 


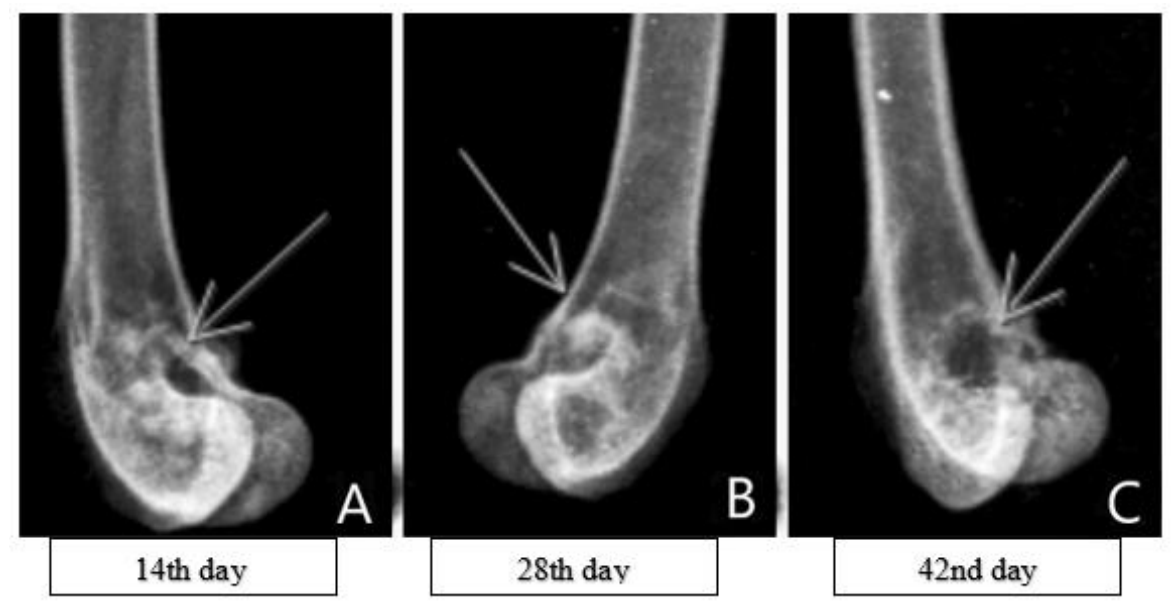

Fig. 5. X-ray result from the right distal femur of rabbits on control days 14 (A), 28 (B) and 42 (C). Black circle indicated the location of the defect.
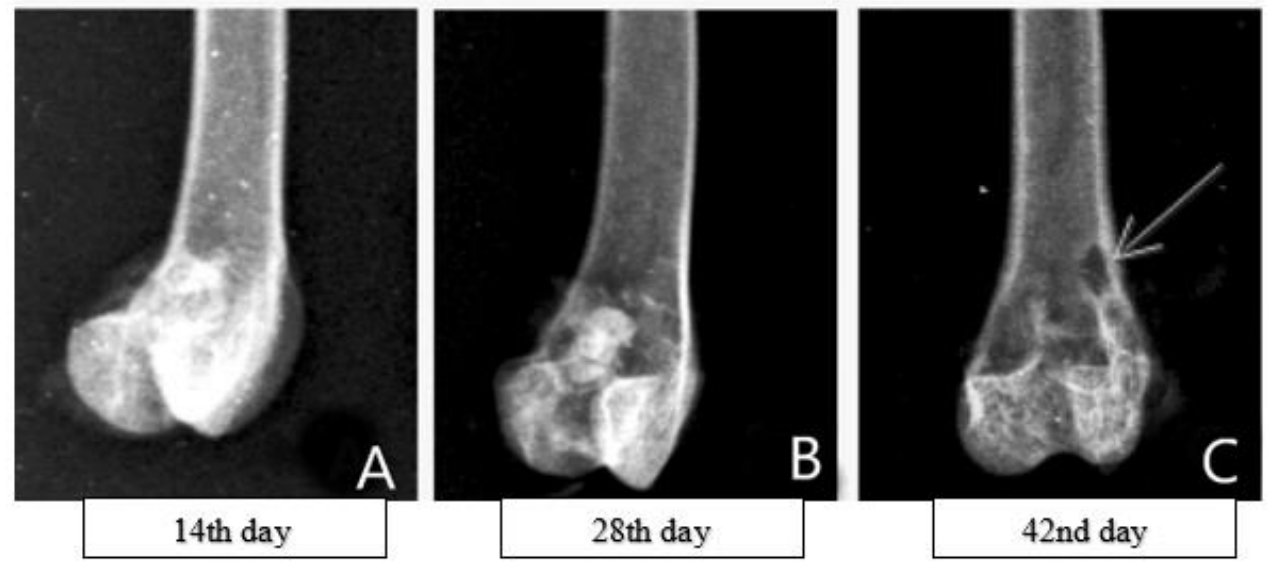

Fig. 6. X-ray result from the right distal femur of rabbits that had been implanted with BHA on days 14 (A), 28 (B), and 42 (C). White circle showed the location of the BHA implantation.

This indicates the process of degradation of BHA-GEN implant continues. The shape of the implant looks fragmented and the size becomes a little smaller. This further confirms the absorption of the implant and the ongoing process of osteogenesis. Bone growth begins with the formation of osteoid by osteoblast of which $90 \%$ of the main constituents is type 1 collagen as the result of implant degradation, namely GEL. Another degradation result from BHA-GEN implant supports the process of bone remodeling by forming osteocyte, this is a good process to accelerate the closure of bone defect.

Bone damage for various reasons will activate all osteoblasts intraosseous and periosteum maximally in damaged areas. Shortly afterwards, a new number of osteoblasts are formed from osteoprogenitor cell, which are bone stem cells in the surface tissue that lines the bone. A callus formation from osteoblastic tissue and a new organic bone matrix which will be followed by withdrawal of calcium salt between the two edges of bone damage in a short time (Narbat et al 2006, Guyton \& Hall 2007, Einhorn 2010). In the process of bone healing, there are two callus types, which are smooth callus (primary callus) and hard callus (secondary callus). Primary callus are formed in the third week to the fourth week after the occurrence of bone damage, whereas secondary callus are formed in the third to fourth month after the occurrence of bone damage. 

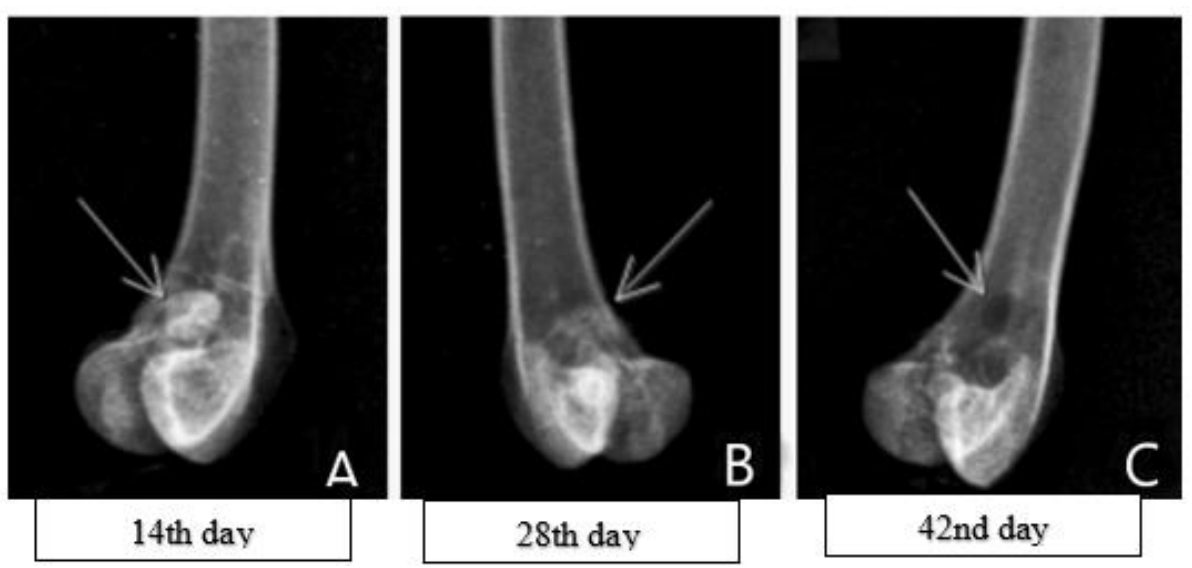

Fig. 7. X-ray result from the right distal femur of rabbits that had been implanted with BHA-GEN on days 14 (A), 28 (B), and 42 (C). White circle indicate the location of BHA-GEN implantation.

Table 2. BALP levels in the control, BHA implant, and BHA-GEN implant groups on days 14, 28 and 42 after fracture induction. $*$ ) showed a significant difference between the control group with BHA or BHA-GEN group $(p=0.0361)$ on the $14^{\text {th }}$ day.

\begin{tabular}{cccc}
\hline \multirow{2}{*}{ Group } & \multicolumn{3}{c}{ BALP level $(\mathbf{X} \pm$ SD) level on the day of } \\
\cline { 2 - 4 } & $\mathbf{1 4}^{\text {th }}$ & $\mathbf{2 8}^{\text {th }}$ & $\mathbf{4 2}^{\text {nd }}$ \\
\hline Control & $30.824 \pm 2.381$ & $25.734 \pm 4.951$ & $19.137 \pm 2.181$ \\
BHA & $24.753 \pm 1.502^{*}$ & $21.082 \pm 1.504$ & $19.725 \pm 0.834$ \\
BHA-GEN & $20.242 \pm 0.907^{*}$ & $22.026 \pm 1.480$ & $22.126 \pm 2.474$ \\
\hline
\end{tabular}

BALP is an isoenzyme that shows the formation of bone and the main enzyme that is present in inorganic change in pyrophosphate which is the inhibitor of bone mineralization (Goes et al 2012, Saosa et al 2015). BALP can be an early marker of osteoblast differentiation, and increases when progressive differentiation of osteoblasts occurs (Boanini et al 2008, Silva et al 2015). Analysis of BALP level seen in table 2 shows that the analysis of the level of alkaline phosphatase enzyme on days 14, 28, and 42 shows an increase in soft callus formation on day 14 because there has been a reaction between osteoblast and collagen type 1 forming soft callus, osteoblast react switch calcium and phosphate to form hydroxyapatite which settles, this is accelerated by the presence of hydroxyapatite from the BHA and BHA-GEN implant matrices. The testing using Tukey's multiple comparisons test shows a significant difference between the BHA and BHA-GEN groups compared to control group ( $\mathrm{p}<0.0361$ ) on day 14 or phase production matrix, as well as on days 28 and 42 . This result proves that bone alkaline phosphatase has enzymatic activity that shows an association with remodeling activity on the 14th day of repairing phase. Microscopic examination result with $\mathrm{HE}$ staining shows that the number of BHA and BHA-GEN osteocytes increase when compared with control group on days 14,28 , and 42.
Bone-specific alkaline phosphatase (BALP) is an isoenzyme for monitoring metabolic activity in bone synthesized in osteoblast and reflects osteoblast activity during bone formation, the production of the main protein in form is collagen type 1 (Greenblatt et al, 2017). Alkaline phosphatase degrades matrix that is rich in proteoglycans and hydrolyzes high ester energy to provide phosphate ion resulting in the deposition of minerals with calcium in a collagen-rich matrix network. Precipitation of calcium and phosphate minerals with ALP can cause bone formation so that when bone formation can be increased then fracture healing can also be faster.

Based on this research data, it shows that BHA and BHA-GEN implants can accelerate the process of bone growth. For this reason, the use of BHA and BHA-GEN implants is predicted to provide greater benefits along with ongoing efforts to develop a new strategy in the treatment of fracture illness. For this reason, it is necessary to further study the mechanism pathways and other markers in order to fully explain the process of bone remodeling acceleration.

\section{REFERENCES}

Askarzadeh K, People F, Moztarzadeh F (2005). Fabrication and characterization of a porous compo- 
site implant based on gelatin and hydroxyapatite for bone tissue engineering. Iranian Polymer Journal 14, 511-520

Azami M, Tavakol S, Samadikuchaksaraei A, Hashjin SM, Baheiraei N, Kamali M, Nourani MR (2012). A porous hydroxyapatite/gelatin nanocomposite implant for bone tissue repair: In vitro and in vivo evaluation. Journal of Biomaterial Science 23, 2353-2368

Boanini E, Torricelli P, Gazzano M, Giardino R, Bigi A (2008). Alendronate - hydroxyapatite nanocomposites and their interaction with osteoclasts and osteoblast like cells. J. Biomaterials 29, 790-796

Brunner \& Suddarth (1997). Brunner and Suddarth's Journal of Medical-Surgical Nursing . 7th Ed. 6-15.

Budiatin Aniek Setiya, et al (2013). Gentamicin release from bovin-hydroxy-apatite-gelatin implant as a drug and bone filling delivery system. Indonesian Journal of Pharmacy and Pharmaceutical Sciences 1, 10-11

Budiatin AS, Zainuddin M, Khotib J (2014). Biocompatable composite as gentamicin delivery system for osteomyelitis and bone regeneration. International Journal of Pharmacy and Pharmaceutical Sciences 6, 223-226

Capra P, Dorati R, Colonna C, Giovanna B, Pavanetto, F, Genta I, Conti B (2011). A preliminary study on the morphological and release properties of hydroxyapatite-alendronate composite materials. Journal of Microencapsulation 28, 395-405

Cattalini JP, Boccaccini AR, Habil Dr.-Ing, Lucangioli S, Mourino V (2012). Bisphosphonate-based strategies for bone tissue engineering and orthopedic implants. Tissue Engineering Part B 18, 5-8

Chang J, Lin K (2015). Structure and properties of hydroxyapatite for biomedical applications. Hap for Biomedical Applications, 3-19

Chao SC, Wang MJ, Pai NS, Yen SK (2015). Preparation and characterization of gelatinhydroxyapatite composite microspheres for hard tissue repair. Materials Science and Engineering C 57, 113122

Chen G, Deng C, Li YP (2012). TGF- $\beta$ and BMP signaling in osteoblast differentiation and bone formation. International Journal of Biological Sciences 8, 272-288

Cottrell JA, Vales FM, Schachter D, Wadsworth S, Gundlapalli R, Kapadia R, O'Connor JP (2010). Osteogenic activity of locally applied small molecule drugs in a rat femur defect model. Journal of Biomedicine and Biotechnology 597641, 1-2

Einhorn TA (2010). Can an anti-fracture agent heal fractures?. Clinical Cases in Minerals and Bone Metabolism 6, 251-253

Einhorn TA, Gerstenfeld LC (2014). Fracture healing: Mechanism and interventions. Nature Reviews Rheumatology, 355-337
Ellis EG, Kathleen B (2007). The role of alkaline phosphatase in mineralization. Curr Opin Orthop 18, 444-448

Ferdiansyah, Rushadi D, Rantam FA, Aulani'am (2010). Regeneration of massive bone defect with bovine hydroxyapatite as mesenchymal stem cells' implants 13, 179-195

Fischer AH, Jacobson KA, Rose J, Zeller R (2008). Hematoxylin and eosin staining of tissue and cell sections. Cold Spring Harbor Protocols 3, 4986-4988

Goes P, Melo MI, Dutra SC, Lima SPA, Lima V (2012). Effect of alendronate on bone - specific alkaline phosphatase on periodontal bone loss in rats. Archives of Oral Biology 57, 1537-1274

Greenblatt MB, Tsi JN, Wein, MN (2017). Bone turnover markers in the diagnosis and monitoring of metabolic bone disease. Clinical Chemistry 63, 464474

Guyton AC, Hall JE (2007). Medical physiology textbook. 9th Ed. Jakarta, EGC, p 6-7

Hikmawati D, Maulida HN, Putra AP, Budiatin AS and Syahrom A (2019). Synthesis and characterization of nanohydroxyapatite-gelatin composite with streptomycin as antituberculosis injectable bone substitute. International Journal of Biomaterials 2019

Kalfas IH (2001). Principles of bone healing. Neurosurg Focus 10, 7-10

Kim, HW, Knowles, JC, Kim HE (2004). Hydroxyapatite and gelatin composite foams processed via novel freeze-drying and crosslinking for use as temporary hard tissue implants. Journal of Biomedical Materials Research - Part A 72, 136-145

Kusrini E, Sontang M (2012). Characterization of X-ray diffraction and electron spin resonance: Effects of sintering time and temperature on bovine hydroxyapatite. Rad Physical and Chem, 118-125

Marsell R, Einhorn TA (2011). The biology of fracture healing. Injury 42, 551-555

Maulida HN, Hikmawati D, Budiatin AS (2015). Injectable bone substitute paste based on hydroxyapatite, gelatin and streptomycin for spinal tuberculosis. The Spine Journal 4, 4-7

Narbat KM, Orang F, Hashtjin SM, Goudarzi A (2006). Fabrication of porous hydroxyapatite-gelatin composite implans for bone tissue engineering. Iranian Biomed J. 10, 215-223

Ning B, Zhao Y, Buza III JA, Li W, Wang W, Jia T (2017). Surgically-induced mouse models in the study of bone regeneration: Current models and future directions. Molecular Medicine Reports 15, 10171023

Pagani F, Francucci CM, Moro L (2005). Markers of bone turnover: Biochemical and clinical perspectives $\mathbf{J}$ Endocrinol Invest 28, 8-13 
Raggatt LJ, Partridge NC (2010). Cellular and molecular mechanism of bone remodeling. Journal of Biological Chemistry 285, 25103-25108

Ramirez-Fernandez MP, Calvo-Guirado JL, DelgadoRuiz RA, Mate-Sanchez del Val JE, Gomez-Moreno G, Guardia J (2011). Experimental model of bone response to xenografts of bovine origin (Endone®): a radiological and histomorphometric study. Clin.Oral Impl.Res 22, 727-734

Schlickewei WC, Laaff G, Andresen A, Klatte OT, Rueger Mj, Ruesing J, Epple M, Lehmann W (2015). Bone augmentation using a new injectable bone graft substitute by combining calcium phosphate and bisphosphonate as composite - an animal model. Journal of Orthopedic Surgery and Research 10, 116

Seibel MJ (2000). Molecular markers of bone turnover: biochemical, technical and analytical aspects.
International Osteoporosis Foundation and National Osteoporosis Foundation 6, S18-29

Sihombing D, Nursiswati, Prawesti A (2012). Overview of foot care and sensory sensation of feet in patients with type 2 diabetes mellitus in the $\mathrm{dm}$ polyclinic hospital

Silva RF, Sasso GRD, Cerri ES, Simoes MJ, Cerri PS (2015). Review article. Biology of bone tissue: structure, function, and factors that influence bone cells. BioMed Research International 2015, 1-17

Sousa CP, Dias IR, Pena ML, Camassa JA, Lourenco PJ, Judas FM, Gomes ME, Reis RL (2015). Bone turnover markers for early detection of fracture healing disturbances. Anais da Academia Brasileira de Ciencias 87, 1049-1061 